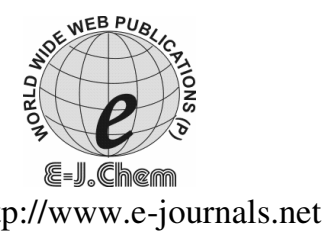

ISSN: 0973-4945; CODEN ECJHAO

E-Journal of Chemistry 2010, 7(2), 473-478

\title{
Assessment of Groundwater Pollution and its Impact in and around Punnam Area of Karur District, Tamilnadu, India
}

\author{
G. RAJA* and P. VENKATESAN \\ *Department of Chemistry, Paavai Engineering College, \\ Namakkal - 637 018, Tamilnadu, India. \\ Department of Chemistry, Mahendra Institute of Technology, \\ Namakkal - 637 503, Tamilnadu, India. \\ paavairaja@yahoo.com
}

Received 8 October 2009; Accepted 5 December 2009

\begin{abstract}
Various samples of groundwater were collected from different areas in and around the Punnam village of Karur District, India and analyzed for their physicochemical characteristics. The results of this analysis were compared with the water quality standards of WHO and CPHEEO. In this analysis the various physicochemical parameters such as $\mathrm{pH}$, electrical conductivity, turbidity, total dissolved solids, $\mathrm{Cl}^{-}, \mathrm{F}^{-}, \mathrm{SO}_{4}{ }^{2-}, \mathrm{NO}_{3}^{-}, \mathrm{Na}^{+}, \mathrm{K}^{+}, \mathrm{Fe}$, $\mathrm{Cr}$, calcium and magnesium etc., were determined using standard procedures. The quality of groundwater samples were discussed with respect to these parameters and thus an attempt were made to ascertain the quality of groundwater used for drinking and cooking purposes in the sampling areas.
\end{abstract}

Keywords: Groundwater, Physiochemical parameter, Water quality, Correlation coefficient.

\section{Introduction}

Water sources available for drinking and other domestic purposes must possess high degree of purity, free from chemical contamination and microorganisms. The rapid growth of urban areas has further affected the groundwater quality due to over exploitation of resources and improper waste disposal practices ${ }^{1}$. Also, the effluent from the textile industry are characteristics of waste water released from sizing, desizing, kiering, bleaching, mercerizing, dye house and printing sections of composite cotton textile mills. The wastewater is highly viscous with high suspended solids and total dissolved solids ${ }^{2}$. Therefore, pollution of water resources needs a serious and immediate attention through periodical checkup of water quality. The purpose of this study was to evaluate the composition and quality of groundwater and the saline water intrusion in and around the Punnam village of Karur District, India. 


\section{Experimental}

The study area, the Punnam village, is situated $\left(11^{\circ} 0^{\prime} 23^{\prime \prime} N\right.$ and $\left.77^{\circ} 57^{\prime} 47^{\prime \prime} \mathrm{E}\right)$ in $8 \mathrm{~km}$ away from Karur District of Tamilnadu, India. The Punnam village is spread over $17 \mathrm{sq} . \mathrm{km}$ and having population about 12,000. As large textile industries are situated in the Karur district, the ground water gets contaminated at highest rate. Particularly, Punnam village is depending on textile industries, wells and bore wells are significantly polluted. Hence, it is proposed to study the ground water pollution and its impact in and around the Punnam village.

Overall, 30 samples (3 samples from each location) were collected from the bore wells of various places in and around of Punnam in Karur district and during this collection the distance between one and other location was maintained at a minimum of one kilometer in order to carry out a broad study on the quality of water in this area. The area of the sample collected includes; Pasupathipalayam (1), Kulathur (2), Naduppalayam (3), Chathiram (4), Sadaiyampalayam (5), Govindampalayam (6), Kuttakadai (7), Kuppam (8), Pavithram (9), Punnam (10).

\section{Collection of samples}

Various water samples were collected in clean and dry polyethylene bottles from bore wells after running them for 5 minutes. All the collection of samples are immediately preserved in dark boxes and processed for the different analysis within 6 hours after collection. In this present study, various physical and chemical parameters of water samples were determined and the results were compared with the values of various water quality standards such as World Health Organization (WHO) and Central Public Health and Environmental Engineering Organization (CPHEEO).

\section{Physicochemical analysis}

The temperature of the samples was noted at their sampling point itself. The samples collected were analyzed for important physical and chemical parameters such as temperature, taste, turbidity, conductivity, $\mathrm{pH}$, hardness, total solids, total dissolved solids, total suspended solids, chlorides, sulphate, nitrate, fluorides dissolved oxygen, sodium, potassium and heavy metals. Standard procedure involving spectrophotometry, flame photometry and volumetry were used for the experiment ${ }^{3}$.

\section{Bacteriological analysis}

In bacteriological examination ${ }^{4}$, total coliforms $\left(28{ }^{\circ} \mathrm{C}\right.$ for $\left.24 \mathrm{~h}\right)$ and faecal coliforms $\left(44.5{ }^{\circ} \mathrm{C}\right.$ for $\left.24 \mathrm{~h}\right)$ were determined by Membrane Filtration (MF) technique, and the average values were recorded. The TC was enumerated by M-Endo Agar, (Hi-Media Mumbai) which appeared as metallic sheen colour colonies, and FC was enumerated by M-FC Agar, (Hi-Media Mumbai) which appeared as blue colour colonies.

\section{Results and Discussion}

The various physical, chemical and biological parameters determined for the water samples were given in Tables 1, 2 and 3 respectively. The statistical evaluation was given in Table 4 . From the analyzed results it was found that the quality of water considerably varies from location to location. 
Table 1. Physical parameters, in $\mathrm{mg} / \mathrm{L}$

\begin{tabular}{lcccccccccc}
\hline Parameters & $\mathbf{1}$ & $\mathbf{2}$ & $\mathbf{3}$ & $\mathbf{4}$ & $\mathbf{5}$ & $\mathbf{6}$ & $\mathbf{7}$ & $\mathbf{8}$ & $\mathbf{9}$ & $\mathbf{1 0}$ \\
\hline Temp, ${ }^{\circ} \mathrm{C}$ & 31.5 & 31.5 & 32.5 & 31 & 30 & 31.5 & 29.5 & 29.5 & 30.5 & 30.0 \\
Colour & CL & CL & CL & CL & CL & CL & CL & CL & CL & CL \\
Odour & OL & OL & OL & OL & OL & OL & OL & OL & OL & OL \\
Taste & S & B & SS & B & N & SS & SS & SS & N & SS \\
Turbidity & CLR & CLR & CLR & CLR & CLR & CLR & CLR & CLR & CLR & CLR \\
Conductivity & 2.16 & 2.91 & 1.59 & 2.80 & 1.01 & 2.14 & 2.06 & 2.09 & 1.16 & 1.93 \\
Total solids & 2,125 & 2,845 & 1,695 & 3,020 & 925 & 2,060 & 2,328 & 2,080 & 988 & 1,885 \\
TDS & 2,065 & 2,790 & 1,675 & 2,940 & 905 & 2,030 & 2,278 & 2,040 & 968 & 1,865 \\
TSS & 60 & 55 & 20 & 80 & 20 & 30 & 50 & 40 & 20 & 20 \\
\hline
\end{tabular}

CL-Colourless; OL-Odourless; $S$-Salt; SS - Slightly Salt; N-Normal; B-Bitter; CLR-Clear; TDS - Total Dissolved Solid; TSS - Total Suspended Solid

\section{Physical parameters}

As far as the physical parameters are concerned all the samples were appeared colorless, clear and odourless. The temperature of the sample is lies between 29.5 to $32.5{ }^{\circ} \mathrm{C}$. The increase in the temperature decreases the portability of water due to expel of taste imparting $\mathrm{CO}_{2}$ and others gases. Thus, the taste of sample differs from place to place ${ }^{5}$.

Table 2. Chemical parameters, in $\mathrm{mg} / \mathrm{L}$.

\begin{tabular}{lcccccccccc}
\hline \multicolumn{1}{c}{ Parameters } & $\mathbf{1}$ & $\mathbf{2}$ & $\mathbf{3}$ & $\mathbf{4}$ & $\mathbf{5}$ & $\mathbf{6}$ & $\mathbf{7}$ & $\mathbf{8}$ & $\mathbf{9}$ & $\mathbf{1 0}$ \\
\hline $\mathrm{pH}$ & 8.6 & 8.0 & 8.5 & 8.0 & 7.3 & 8.7 & 7.8 & 7.3 & 7.4 & 8.1 \\
Total hardness & 315 & 455 & 225 & 520 & 210 & 245 & 912 & 424 & 188 & 245 \\
Total Alkalinity & 818 & 725 & 388 & 905 & 315 & 445 & 894 & 495 & 310 & 325 \\
Calcium & 205 & 165 & 71 & 223 & 85 & 92 & 124 & 85 & 98 & 106 \\
Hardness & & & & & & & & & & \\
Magnesium & 147 & 68 & 96 & 88 & 75 & 112 & 52 & 126 & 78 & 64 \\
Hardness & & & & & & & & & & \\
Sodium & 550 & 470 & 420 & 390 & 170 & 330 & 340 & 350 & 180 & 450 \\
Potassium & 135 & 95 & 80 & 40 & 20 & 40 & 40 & 30 & 20 & 40 \\
Iron & 0.2 & 0.3 & 0.1 & 0.2 & 0.3 & 0.2 & 0.1 & 0.2 & 0.4 & 0.2 \\
Chromium & 0.06 & 0.09 & 1.0 & 0.07 & 0.09 & 0.05 & 0.08 & 0.07 & 0.06 & 0.09 \\
Chloride & 195 & 305 & 158 & 382 & 125 & 228 & 115 & 195 & 178 & 125 \\
Sulphate & 165 & 228 & 104 & 290 & 115 & 196 & 75 & 148 & 155 & 195 \\
Nitrate & 75 & 40 & 40 & 35 & 20 & 25 & 15 & 30 & 40 & 50 \\
Fluoride & 0.72 & 0.82 & 0.57 & 1.20 & 0.68 & 1.30 & 0.91 & 0.89 & 0.75 & 0.30 \\
\hline
\end{tabular}

Table 3. Biological parameters, in $\mathrm{mg} / \mathrm{L}$.

\begin{tabular}{lcccccccccc}
\hline \multicolumn{1}{c}{ Parameters } & $\mathbf{1}$ & $\mathbf{2}$ & $\mathbf{3}$ & $\mathbf{4}$ & $\mathbf{5}$ & $\mathbf{6}$ & $\mathbf{7}$ & $\mathbf{8}$ & $\mathbf{9}$ & $\mathbf{1 0}$ \\
\hline Dissolved & 2.2 & 2.5 & 3.5 & 1.6 & 5.5 & 2.4 & 2.6 & 2.3 & 3.9 & 3.7 \\
oxygen & 65.4 & 85.2 & 47.0 & 98.5 & 46.0 & 65.7 & 67.8 & 62.0 & 51.0 & 48.0 \\
COD & 2.5 & 3.2 & 1.4 & 3.1 & 1.2 & 2.6 & 2.3 & 1.9 & 1.4 & 1.5 \\
BOD & 50 & 80 & 40 & 70 & 20 & 70 & 50 & 70 & 30 & 100 \\
faecal coliforms, & MPN/100 mL & & & & & & & & &
\end{tabular}




\section{Chemical parameters}

Conductance of water samples varied from 1.01 to $2.91 \mathrm{mS} / \mathrm{cm}$. But samples 2 and $\mathbf{4}$ had relatively higher conductivity, which may be due to contamination of conducting material in water samples. According to WHO and CPHEEO Standards, the acceptance limit for TDS in groundwater is $500 \mathrm{mg} / \mathrm{L}$, which may go up to $1500 \mathrm{mg} / \mathrm{L}$ in case of any alternative source. But, almost all the samples exceed the permissible limit and sample $\mathbf{5}$ and $\mathbf{9}$ are found moderately hard.

The $\mathrm{pH}$ values of all the sample shows in the range of $\mathrm{pH} 7.3$ to 8.7 , which indicates they were with in the desirable limit except sample 6. The mild alkalinity may be due to the bicarbonates. The alkalinity of the samples $\mathbf{1 , 2}, \mathbf{4}$ and $\mathbf{7}$ are found to be high due to more seepage of effluent, domestic sewage around the stations.

Table 4. The minimum, maximum, average concentration and standard deviation of chemical parameter with water quality standard.

\begin{tabular}{lcccccc}
\hline \multirow{2}{*}{$\begin{array}{c}\text { Chemical } \\
\text { Parameters }\end{array}$} & \multicolumn{3}{c}{ Observed Concentration } & \multicolumn{2}{c}{ Water Quality } \\
& Min. & Max. & Mean & Std. Dev. & WHO & CPHEEO \\
\cline { 2 - 7 } Temp & 29.50 & 32.50 & 30.75 & 1.01 & 30 & 30 \\
Conductivity & 1.01 & 2.91 & 1.99 & 0.61 & 1.8 & 1.4 \\
TS & 925.00 & 3020.00 & 1995.10 & 680.96 & 500 & 500 \\
pH & 7.30 & 8.70 & 7.97 & 0.53 & $6.5-8.5$ & $6.5-9.2$ \\
Total Alkalinity & 310.00 & 905.00 & 562.00 & 247.01 & 250 & 250 \\
Total hardness & 188.00 & 912.00 & 373.90 & 221.18 & 500 & 600 \\
Ca $^{2+}$ Hardness & 71.00 & 223.00 & 125.40 & 53.64 & 75 & 200 \\
Mg $^{2+}$ Hardness & 52.00 & 147.00 & 90.60 & 29.89 & 50 & 150 \\
Sodium & 170.00 & 550.00 & 365.00 & 120.39 & 100 & 100 \\
Potassium & 20.00 & 135.00 & 54.00 & 37.40 & 10 & 10 \\
Iron & 0.10 & 0.40 & 0.22 & 0.09 & 0.3 & 1.0 \\
Chromium & 0.05 & 1.00 & 0.17 & 0.29 & 0.05 & 0.05 \\
Chloride & 115.00 & 382.00 & 200.60 & 85.44 & 250 & 1000 \\
Sulphate & 75.00 & 290.00 & 167.10 & 63.35 & 200 & 400 \\
Nitrate & 15.00 & 75.00 & 37.00 & 17.03 & 45 & 45 \\
Fluoride & 0.30 & 1.30 & 0.81 & 0.29 & $1-1.5$ & 1.5 \\
DO & 1.60 & 5.50 & 3.02 & 1.14 & 5.0 & - \\
COD & 46.00 & 98.50 & 63.66 & 17.32 & - & - \\
BOD & 1.20 & 3.20 & 2.11 & 0.73 & - & - \\
f. coliforms, & 20.00 & 100.00 & 58.00 & 24.40 & - & - \\
MPN/100 mL & & & & & \\
\hline
\end{tabular}

The total hardness is relatively high in all samples due to the presence of calcium, magnesium, and chloride and sulphate ion. Hence, the water available in these areas is not suitable for drinking, washing, cleaning and laundering purpose. Also, leads to heart diseases and kidney stone formation ${ }^{6}$.

Sodium and potassium of water samples collected lies in the range of 170 to $550 \mathrm{mg} / \mathrm{L}$ and 20 to $135 \mathrm{mg} / \mathrm{L}$ respectively. These values are exceeds the permissible limit proposed by WHO and CPHEEO. Thus, the excess amount of potassium present in the water sample may leads nervous and digestive disorder ${ }^{7}$. Except sample 1, all has chloride content more than permissible limit. And also, fluoride was found with in the permissible limit for all samples. 
High amount of sulphate imparts bitter taste to the sample $\mathbf{2}$ and $\mathbf{4}$. Also, this will cause laxative effect to the children in hot weather climates ${ }^{8}$. As sample $\mathbf{1}$ and $\mathbf{1 0}$ has nitrate concentration above permissible limit $(45 \mathrm{mg} / \mathrm{L})$ according to WHO, It has been reported that nitrate concentration causes Methemoglobinemia and cyanosis in these sampling area ${ }^{9}$.

\section{Biological parameter}

The DO level of all samples except station 5 shows very low value because of the effluent from the industries containing high amount of organic wastes depletes the oxygen level. It is observed from the experimental data that the COD ranges from 46 to $98.5 \mathrm{~g} / \mathrm{L}$, which exist in the permissible limit except sample $\mathbf{2}$ and $\mathbf{4}$. It clearly indicates the toxic nature of water found in those areas. Also, it was further confirmed by higher concentration of BOD found in those areas. Hence, water from sampling area $\mathbf{2}$ and $\mathbf{4}$ was not suitable for drinking purpose. The faecal coliforms values are in the range of 20 to $100 \mathrm{MPN} / 100 \mathrm{~mL}$. This is higher than the permissible limit according to ISI. Hence, they may not be used for drinking purpose.

Table 5. Correlation coefficient ( $r$ ) for different parameter.

\begin{tabular}{lccccccccccc}
\hline Parameters & EC & $\mathrm{pH}$ & $\mathrm{TH}$ & $\mathrm{TA}$ & $\mathrm{Ca}^{2+}$ & $\mathrm{Mg}^{2+}$ & $\mathrm{Na}^{+}$ & $\mathrm{K}^{+}$ & $\mathrm{Cl}^{-}$ & $\mathrm{SO}_{4}^{2-}$ & $\mathrm{NO}_{3}{ }^{-}$ \\
\hline EC & 1.00 & & & & & & & & & & \\
pH & 0.38 & 1.00 & & & & & & & & & \\
Total & 0.48 & 0.12 & 1.00 & & & & & & & & \\
Hardness & & & & & & & & & & & \\
Total & 0.74 & 0.23 & 0.78 & 1.00 & & & & & & & \\
Alkalinity & & & & & & & & & & & \\
Calcium & 0.69 & 0.27 & 0.34 & 0.82 & 1.00 & & & & & & \\
Magnesium & 0.10 & 0.36 & 0.33 & 0.07 & 0.17 & 1.00 & & & & & \\
Sodium & 0.69 & 0.68 & 0.16 & 0.50 & 0.54 & 0.34 & 1.00 & & & & \\
Potassium & 0.42 & 0.65 & 0.01 & 0.44 & 0.52 & 0.45 & 0.82 & 1.00 & & & \\
Chloride & 0.75 & 0.18 & 0.11 & 0.51 & 0.69 & 0.16 & 0.28 & 0.19 & 1.00 & & \\
Sulphate & 0.67 & 0.22 & 0.12 & 0.28 & 0.64 & 0.09 & 0.32 & 0.10 & 0.87 & 1.00 & \\
Nitrate & 0.17 & 0.45 & 0.38 & 0.10 & 0.47 & 0.51 & 0.67 & 0.74 & 0.11 & 0.28 & 1.00 \\
\hline
\end{tabular}

\section{Correlation coefficient analysis}

Sources of measured parameters in groundwater were examined through the analysis of linear correlation ${ }^{10}$. The correlation metric for all samples are given in Table 5. We considered the correlation as good if $r>0.6$ and marginal of $0.47<r<0.6$. Since the total hardness and total alkalinity $(\mathrm{r}=0.78)$ has good correlation as well as $\mathrm{pH}$ with Sodium and Potassium ( $\mathrm{r}=0.68,0.65$ respectively), it clearly indicates the level of bicarbonate and carbonate of Sodium and Potassium were found excess in the ground water. Hence, it makes ground water more alkaline. Calcium has good correlation with chloride and sulphate ( $\mathrm{r}=0.69$ and 0.64 respectively) indicating that it is in the form of $\mathrm{CaCl}_{2}$ and $\mathrm{CaSO}_{4}$ so as to produces permanent hardness. Also, Nitrate shows marginal correlation with magnesium $(\mathrm{r}=0.51)$ and good correlation with sodium $(\mathrm{r}=0.67)$ and potassium $(\mathrm{r}=0.74)$. It means that nitrate exist in the non-acidic salt form. Similarly, the conductivity has good correlation with calcium $(r=0.69)$, sodium $(r=0.69)$, chloride $(r=0.75)$ and sulphate $(r=0.67)$.

\section{Conclusion}

The water quality parameter of the various areas around Punnam clearly indicates that the water samples are highly polluted. It is observed that the water taken from Pasupathipalayam, 
Kulathur, Chathiram are alarmingly get polluted followed by Kuttakadai. These areas situated nearer to the textile industries. So, the proper environment management plan may be adopted to control the release of effluent. Hence it is suggested to exercise all the necessary precaution before the water is used for drinking and irrigation. Otherwise, it may lead to much adverse health effect.

\section{References}

1. Rajankar P N, Gulhane S R, Tambekar D H, Ramteke D S and Wate S R, E-Journal of Chemistry, 2009, 6(3), 905.

2. $\quad$ Sekar P, Hariprasad S and Deccaraman M, J Appl Sci Res., 2008, 4(11), 1526.

3. Nagarajan S, Swaminathan M and Sabarathinam P L, Poll Res., 1993, 12(4), 245.

4. Hank Mikaelian, ASHI Technical Journal, 1991, 1(2), 39

5. Karunakaran K, Thamilarasu P and Sharmila R, E-Journal of Chemistry, 2009, 6(3), 909.

6. Lalitha S and Barani A V, Indian J Environ Protect., 2004, 24(12), 925.

7. Tiwari T R, Indian J Environ Health, 2001, 43(1), 176.

8. $\quad$ Gupta and Suruchi, Asian J Chem., 2001, 13(3), 16.

9. Van Grinson H J M, Ward M H, Benjamin N and De Kok T M, Environmental Health, 2006, 5(26), 1.

10. Suresh Tewari, Ashwini Ranade and Deewan Singh, Indian Journal of Radio \& Space Physics, 2006, 35, 35. 


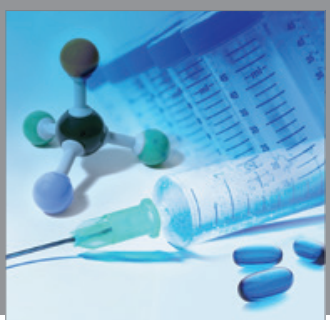

International Journal of

Medicinal Chemistry

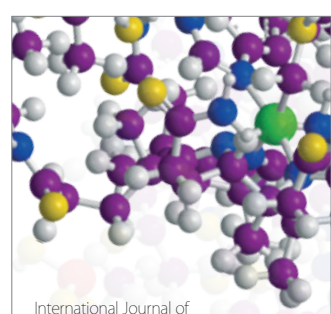

Carbohydrate Chemistry

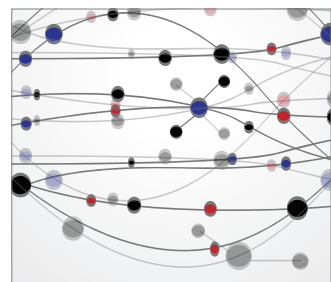

The Scientific World Journal
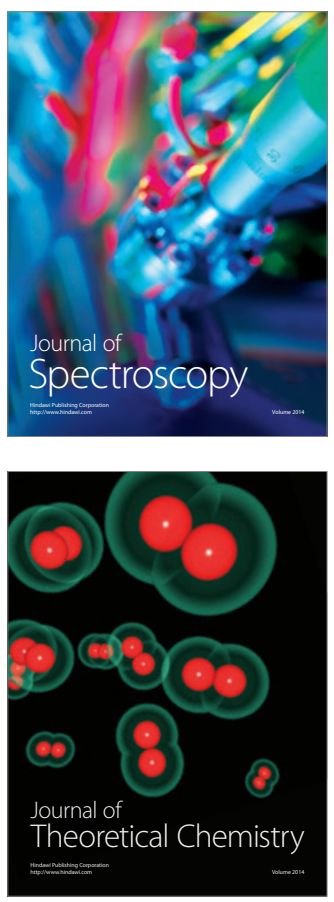
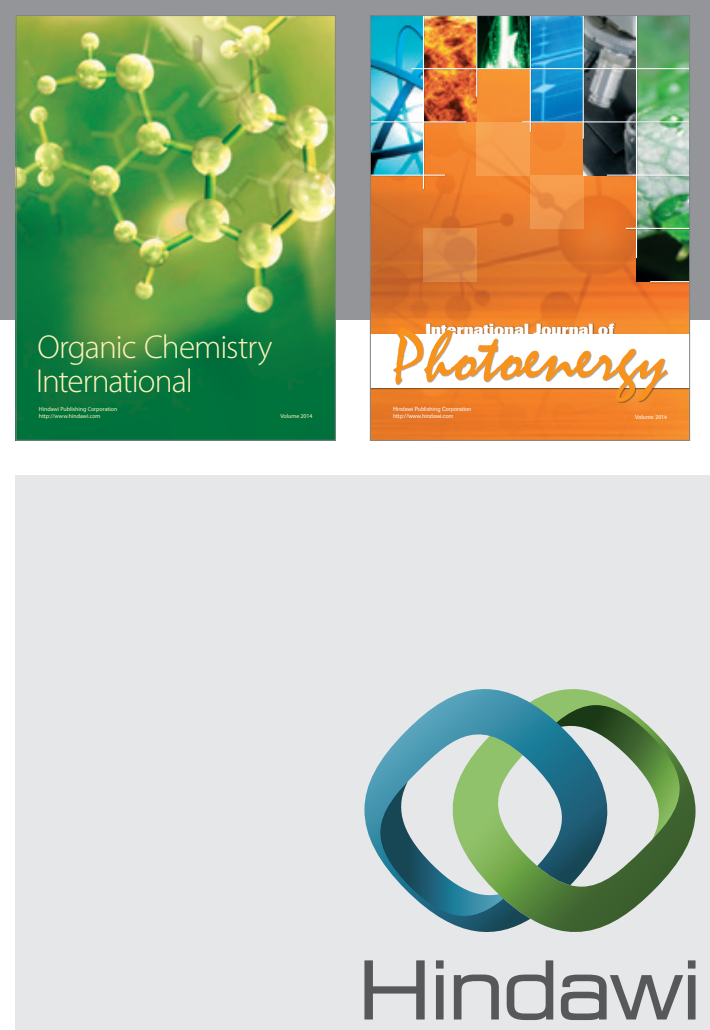

Submit your manuscripts at

http://www.hindawi.com
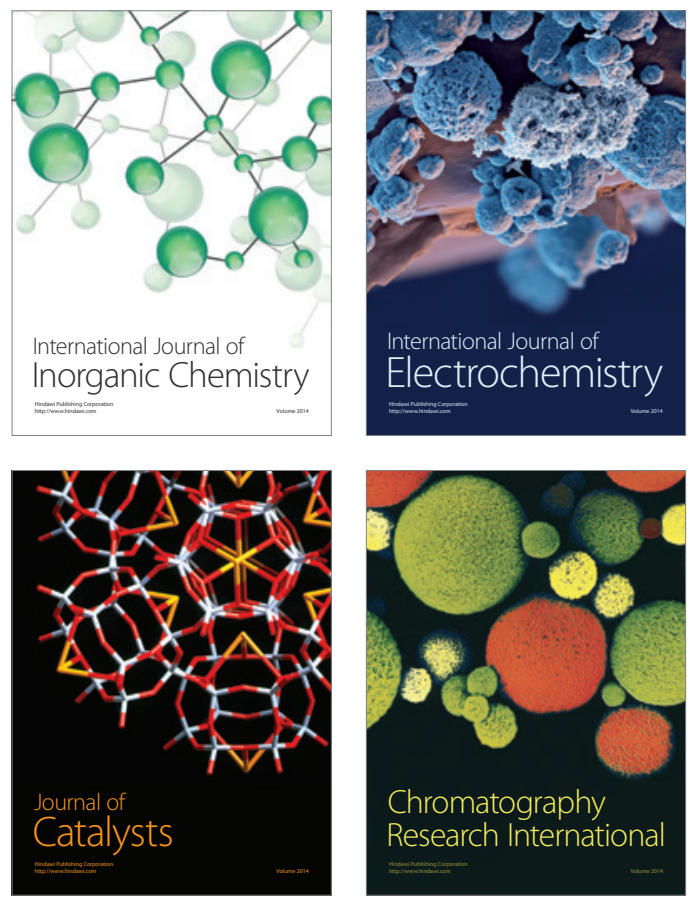
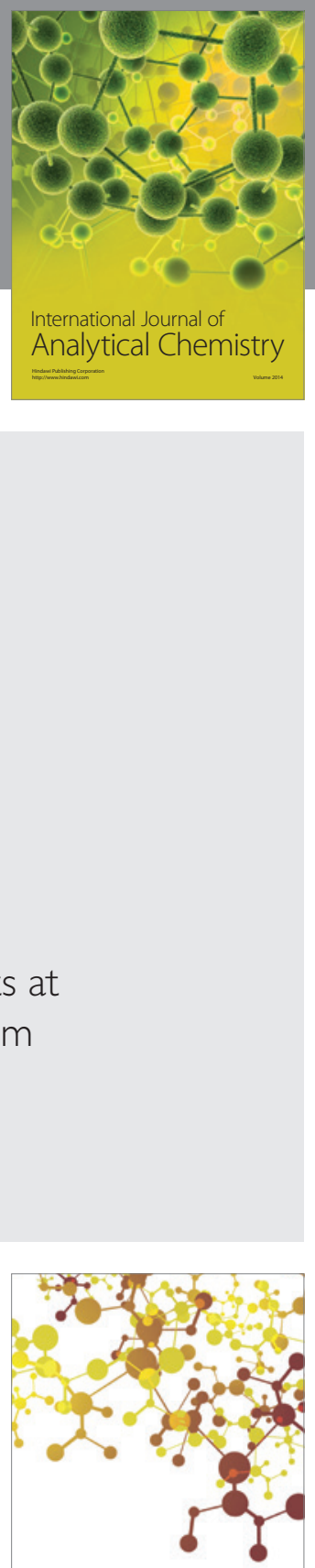

Journal of

Applied Chemistry
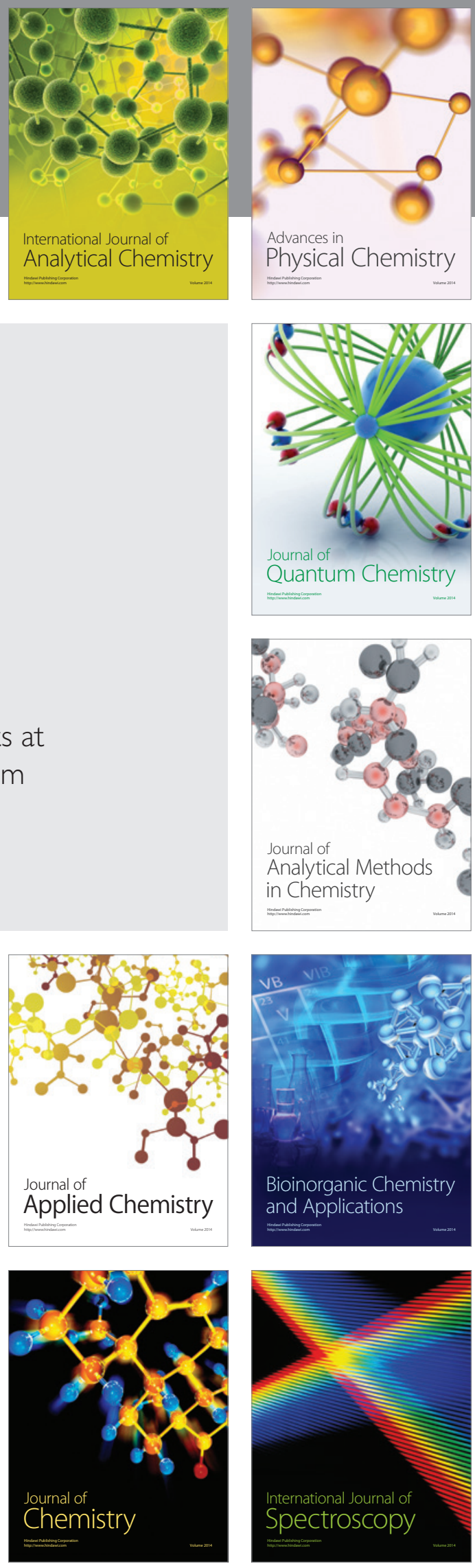